\title{
Tenaga kerja wanita (TKW) dan perubahan sosial yang disebabkannya
}

\author{
Eka Khoirul Ana, I Nyoman Ruja*, I Dewa Putu Eskasasnanda \\ Universitas Negeri Malang, Jl. Semarang No. 5 Malang, Jawa Timur, Indonesia \\ *Penulis korespondensi, Surel: nyoman.ruja.fis@um.ac.id
}

Paper received: 03-02-2021; revised: 15-02-2021; accepted: 28-02-2021

\begin{abstract}
The focus of this research is to analyze 1) the characteristics of TKW; 2) reasons for the overseas mobility carried out by TKW; and 3) social changes that occur in the families of TKW. This research is located in Dawung Village, Ringinrejo District, Kediri Regency. A qualitative approach with this type of descriptive research is used to achieve the focus of this study. The results showed that the characteristics of TKW from Dawung Village were 1) productive age; 2) Low level of education, 3) Total dependable burden of more than 1 person; 4) the occupation which is mostly done is domestic servants; 5) Working in Asian countries. Income that is greater than working in the country is the main reason for TKW to travel abroad. They also want to have business capital, meet their children's educational needs, and are in debt. Social changes that occur in the families of TKW are in the form of changes in the role of family members, child care patterns, ways of communicating, and lifestyle. For further researchers, it is hoped that they can study the social changes of TKW families related to children's education.
\end{abstract}

Keywords: mobility; TKW; social change; family.

\begin{abstract}
Abstrak
Fokus pelaksanaan penelitian ini adalah untuk menganalisis 1) karakteristik TKW; 2) alasan mobilitas ke luar negeri yang dilakukan oleh TKW; dan 3) perubahan sosial yang terjadi pada keluarga TKW. Penelitian ini berlokasi di Desa Dawung Kecamatan Ringinrejo Kabupaten Kediri. Pendekatan kualitatif dengan jenis penelitian deskriptif digunakan untuk mencapai fokus dari penelitian ini. Adapun hasil penelitian menunjukkan bahwa karakteristik TKW dari Desa Dawung yaitu 1) Berusia produktif; 2) Tingkat pendidikan yang rendah, 3) Jumlah beban tanggungan lebih dari 1 orang; 4) pekerjaan yang banyak digeluti adalah pembantu rumah tangga; 5) Bekerja di negara-negara Asia. Penghasilan yang lebih besar dibandingkan kerja di dalam negeri menjadi penyebab utama TKW melakukan mobilitar ke luar negeri. Selain itu, mereka juga ingin memiliki modal usaha, memenuhi kebutuhan pendidikan anak, serta terlilit hutang. Perubahan sosial yang terjadi pada keluarga TKW yaitu berupa perubahan peran anggota keluarga, pola pengasuhan anak, cara berkomunikasi, dan gaya hidup. Bagi peneliti selanjutnya, diharapkan dapat mengkaji mengenai perubahan sosial keluarga TKW terkait dengan pendidikan anak.
\end{abstract}

Kata kunci: mobilitas; TKW; perubahan sosial; keluarga.

\section{Pendahuluan}

Pekerjaan dengan penghasilan yang tinggi banyak diminati oleh tenaga kerja. Namun pekerjaan dengan penghasilan tinggi jumlahnya sedikit, sehingga tingkat persaingan memperoleh pekerjaan semakin tinggi. Hasilanya beberapa perempuan terdorong untuk melakukan mobilitas ke luar negeri untuk menjadi TKW (Tenaga Kerja Wanita). Hal tersebut sesuai dengan pendapat Yuniastuti (2014) yang menyatakan bahwa salah satu alasan memilih bekerja di luar negeri adalah akibat keterbatasan sumber nafkah dari satu keluarga sehingga semua anggota keluarga baik itu laki-laki ataupun perempuan dikerahkan untuk mencari nafkah dan meringankan beban keluarga. 
Mobilitas yang dilakukan oleh TKW berdasarkan observasi awal mengakibatkan perubahan pada keluarga. Salah satunya adalah perubahan sosial. Faktor penyebab perubahan sosial keluarga adalah diferensiasi struktural. Bentuk dari diferensiasi struktural adalah penambahan atau perubahan fungsi dan peran anggota keluarga. Perubahan fungsi dan peran anggota keluarga disebabkan karena harus ada anggota keluarga yang menggantikan fungsi dan peran TKW saat ditinggal bekerja di luar negeri.

Desa Dawung Kecamatan Ringinrejo Kabupaten Kediri merupakan salah satu desa yang pendudukanya banyak menjadi TKW. Di tingkat kecamatan, Desa Dawung berada di urutan ketiga dengan jumlah TKW terbanyak yaitu 157 orang (Badan Pusat Statistika Kabupaten Kediri, 2018). Banyaknya jumlah TKW dari Desa Dawung disebabkan mayoritas penduduk kurang memiliki keterampilan. Faktor lainnya yaitu ketersediaan lapangan pekerjaan yang lebih banyak di bidang pertanian. Hal ini dibuktikan dengan luas lahan pertanian 291.942 ha dari total luas desa 509.494 ha (Badan Pusat Statistika Kabupaten Kediri, 2018). Berdasarkan uraian tersebut maka tidak heran perempuan di Desa Dawung memilih menjadi TKW karena keterampilan yang minim dan kurangnya lapangan pekerjaan dengan penghasilan yang tinggi.

Berdasarkan uraian di atas maka peneliti tertarik untuk meneliti tentang perubahan sosial pada keluarga sebagai akibat dari mobilitar TKW ke luar negeri. Adapun lokasi penelitian adalah di Desa Dawung, Kecamatan Ringinrejo, Kabupaten Kediri. Perubahan sosial pada keluarga TKW menarik untuk diteliti karena perubahan sosial dapat merubah struktur keluarga. Keluarga merupakan lembaga sosial yang unik karena memiliki perbedaan karakteristik yang membedakan dengan keluarga lainnya. Jadi perubahan sosial yang terjadi pada keluarga merupakan perubahan yang unik karena perubahan sosial antar satu keluarga dengan keluarga lainnya tidak sama.

Saat peneliti memutuskan untuk meneliti tentang TKW, peneliti menemukan banyak penelitian. Pertama, penelitian yang dilakukan oleh Wulandari (2013) menemukan bahwa TKW memiliki perilaku konsumtif baik berupa fahion, eletronik, atau bahkan sampai masuk pada ranah perjudian. Hal ini disebabkan adanya persepsi masyarakat, status yang dimiliki TKW, dan keinginan untuk terlihat berbeda dari masyarakat sekitar. Kedua, penelitian yang dilakukan oleh Yuniastuti (2014) menemukan bahwa peran TKI dan TKW sebagai penghimpun dana yang digunakan untuk menyekolahkan anaknya. Namun anak dari TKI dan TKW membuat keributan, merokok, meminum minuman keras dan ke tempat pelacuran. Adapun hal yang unik yang belum dibahas dalam penelitian tersebut adalah alasan TKW melakukan mobilitas ke luar negeri dan perubahan sosial yang terjadi pada keluarganya. Oleh karena itu, dalam penelitiani ini akan dibahas tentang 1) karakteristik TKW, 2) Alasan mereka melakukan mobilitas ke luar negeri; dan 3) perubahan sosial yang terjadi pada keluarga yang ditinggalkan.

\section{Metode}

\subsection{Pendekatan dan Jenis Penelitian}

Dalam mencapai fokus penelitian ini pendekatan kualitatif dipakai karena kemampuannya dalam memahami fenomena yang dialami oleh subjek yang diteliti (Moleong, 2016). Fenomena tersebut antara lain adalah persepsi, perilaku, motivasi, dan tindakan. Sementara dalam penyusunan penelitian ini jenis penelitian deskriptif digunakan untuk menggambarkan subyek atau obyek penelitian pada saat penelitian dilakukan berdasarkan 
fakta-fakta yang tampak. Adapun dalam penelitian ini akan dideskripsikan tentang bentuk perubahan sosial pada keluarga TKW.

\subsection{Lokasi Penelitian}

Penelitian ini berlokasi Desa Dawung Kecamatan Ringinrejo Kabupaten Kediri. Pemilihan lokasi penelitian didasarkan pada pertimbangan bahwa penduduk di Desa Dawung banyak yang memilih bekerja sebagai TKW.

\subsection{Sumber Data}

Penelitian ini menggunakan tiga sumber data, yaitu sumber data berupa kata dan tindakan subjek, data tertulis, dan foto. Sumber data kata-kata dan tindakan didapat melalui wawancara dan pengamatan pada informan pendukung dan informan kunci. Informan pendukung pada penelitian ini adalah kepala desa di Desa Dawung Kecamatan Ringinrejo Kabupaten Kediri. Sementara informan kunci adalah TKW yang sudah menikah dan keluarganya. Sumber data dalam bentuk dokumen tertulis terdiri atas sumber buku dan majalah ilmiah, sumber data dari arsip, dokumen pribadi, dan dokumen resmi. Sumber data yang terakhir adalah foto. Foto dalam penelitian ini digunakan sebagai pelengkap dari sumber data sebelumnya. Foto-foto yang diperlukan dalam penelitian ini adalah informan dan kegiatan pengambilan data.

\subsection{Prosedur Pengumpulan Data}

\subsubsection{Observasi}

Penelitian ini menggunakan observasi terus terang, jadi peneliti menyatakan secara terus terang kepada narasumber (Sugiyono, 2016). Hal ini dilakukan untuk mengetahui alasan mobilitas yang dilakukan oleh TKW dan dampaknya pada perubahan sosial keluarga sehingga narasumber mengetahui sejak awal hingga akhir penelitian.

\subsubsection{Wawancara}

Wawancara adalah percakapan yang dilakukan oleh pewawancara kepada terwawancara dengan maksud tertentu (Moleong, 2016). Untuk mendapat jawaban yang dalam teknik yang digunakan adalah wawancara mendalam dengan pedoman wawancara yang sudah dibuat sebelumnya.

\subsubsection{Dokumentasi}

Dokumen yang dibutuhkan dalam penelitian ini bersifat pribadi dan publik. Dokumen yang bersifat pribadi yaitu foto informan, kegiatan ketika melakukan pengumpulan data, catatan selama di lapangan dan lain sebagainya. Dokumen yang bersifat publik yaitu memo, rekaman, arsip resmi, jurnal, dan artikel atau media cetak lain yang terkait penelitian.

\subsubsection{Analisis Data}

Bersamaan dengan seluruh kegiatan penelitian, analisis data dilakukan secara terus menerus. Hal ini karena penelitian ini mengadopsi model analisis data interaktif. Adapun dalam model interaktif. Adapun dalam model ini terdapat 4 komponen penting yang secara 
simultan berkaitan yaitu pengumpulan data, reduksi data, penyajian data, dan penarikan kesimpulan.

\section{Hasil dan Pembahasan}

\subsection{Karakteristik TKW dari Desa Dawung}

Berdasarkan hasil penelitian diketahui bahwa TKW dari Desa Dawung memiliki beberapa karakteristik. Pertama, TKW dari Desa Dawung berusia produktif yaitu 22 hingga 44 tahun. Hal ini sesuai dengan peraturan Undang-Undang Nomor 39 Tahun 2004 bahwa untuk dapat menjadi tenaga kerja di luar negeri minimal individu harus berusia 18 tahun yang bekerja di bidang formal dan berusia 21 tahun untuk calon TKW yang bekerja pada bidang non formal. Usia produktif merupakan penduduk yang memiliki usia antara 15 hingga 64 tahun (Sukmaningrum, 2017). Disebut sebagai usia produktif karena penduduk yang memasuki usia ini dianggap mampu bekerja pada bidang-bidang tertentu yang dapat menghasilkan barang dan jasa.

Karakteristik kedua, adalah tingkat pendidikan TKW dari Desa Dawung sangat terbatas. yaitu SD dan SMP/MTs. Akses pendidikan yang sangat minim membuat penduduk lebih tertarik menjadi TKW daripada melanjutkan pendidikan ke jenjang yang lebih tinggi. Hal ini didukung oleh temua Dewi, dkk (2014) yang mana faktor akses ke sekolah adalah salah satu penyebab anak putus sekolah.

Ketiga, TKW dari Desa Dawung yang bekerja di luar negeri menjadi domestic workers. Pengertian pekerjaan bidang domestic workers adalah segala jenis pekerjaan yang masuk dalam pekerjaan rumah tangga (Turatmiyah \& Annalisa, 2013). Hal ini dikarenakan latar belakang pendidikan TKW dari Desa Dawung hanya pada tingkat SD dan SMP/MTs. Dengan latar pendidikan ini, TKW kurang mempunyai keterampilan atau kompetensi untuk bekerja pada bidang formal dan pada akhirnya hanya mampu bekerja pada bidang rumah tangga atau domestic workers.

Selanjutnya, karakteristik keempat, TKW dari Desa Dawung adalah berstatus menikah dan memiliki jumlah beban tanggungan keluarga dua sampai tiga orang. Jumlah beban keluarga ini kemudian menyebabkan kebutuhan tidak dapat terpenuhi dari penghasilan di dalam negeri, sehingga pada akhirnya menimbulkan keinginan bekerja di luar negeri sebagai TKW. Informasi ini didukung oleh pendapat Marita \& Waridin (2013) yang menyatakan bahwa jumlah beban tanggungan keluarga berpengaruh pada pengeluaran per bulan sehingga menyebabkan perempuan ikut berpartisipasi untuk bekerja agar kebutuhan hidup dapat terpenuhi.

Terakhir atau karakteristik kelima, TKW dari Desa Dawung memilih negara-negara Asia sebagai tempat tujuan bekerja. Alasan TKW dari Desa Dawung memilih negara-negara Asia yaitu karena letaknya yang dekat dengan Indonesia. Letak yang lebih dekat mempermudah akses untuk menuju ke negara tersebut. Lee (1966) berpendapat bahwa semakin sulit rintangan yang harus dilalui maka akan menurunkan keinginan seseorang untuk melakukan perpindahan ke daerah lain. Hal ini menunjukkan bahwa faktor yang menyebabkan TKW memilih negara-negara Asia adalah rintangan yang mudah dilalui, sehingga meningkatkan minat untuk melakukan perpindahan. 
Alasan lain yang membuat TKW dari Desa Dawung memilih bekerja di negara-negara Asia adalah kemudahan mempelajari bahasa dan penghasilan tinggi. Lee (1966) mengatakan bahwa di setiap daerah ada banyak faktor yang menarik atau menahan seseorang untuk tidak melakukan perpindahan dan juga faktor yang menimbulkan keinginan untuk pindah ke daerah lain. Faktor-faktor tersebut berupa nilai positif yang menimbulkan keuntungan dan nilai negatif yang menimbulkan kerugian. Beberapa faktor yang memberikan nilai positif dan negatif yaitu iklim, biaya pendidikan dan pajak. Dengan demikian, temuan ini memperlengkap temuan dari Lee bahwa selain iklim, biaya pendidikan dan pajak faktor kedekatan kultur juga menjadi daya tarik yang membuat seseorang melakukan perpindahan.

\subsection{Penyebab TKW dari Desa Dawung Melakukan Mobilitas ke Luar Negeri}

Penyebab TKW dari Desa Dawung melakukan mobilitas ke luar negeri berbeda-beda. Alasan pertama adalah keinginan untuk memperbaiki kondisi ekonomi keluarga. Peningkatan ekonomi keluarga dapat dilakukan dengan mendirikan usaha. Para TKW dari Desa Dawung berharap dapat mendirikan usaha dari penghasilannya selama bekerja di luar negeri. Hal ini sesuai dengan hasil penelitian dari Julaiha (2013) seseorang yang menjalankan usaha mengalami peningkatan penghasilan, sehingga perekonomian keluarga menjadi lebih baik. Maka dari itu, tidak heran apabila TKW dari Desa Dawung berharap penghasilan dari bekerja di luar negeri dapat digunakan untuk membuka usaha yang nantinya membuat perekonomian menjadi meningkat.

Selain hal di atas, alasan kedua adalah keinginan untuk memperbaiki pendidikan anak. Febriani (2013) menyatakan bahwa pendidikan saat ini sangat penting karena dapat menjadi investasi modal yang dapat mempengaruhi penghasilan. Pendidikan dapat meningkatkan keterampilan dan keahlian, sehingga pekerjaan yang berpenghasilan besar akan mudah di dapat. Oleh karena itu, diharapkan dengan terpenuhinya kebutuhan pendidikan anak TKW dapat memiliki pekerjaan dengan penghasilan yang besar sehingga perekonomian keluarga menjadi meningkat. Agar dapat meningkatkan pendidikan anak, para TKW bekerja di luar negeri agar mendapatkan penghasilan yang lebih tinggi.

Berdasarkan hasil penelitian diketahui bahwa penghasilan TKW dari Desa Dawung lebih besar daripada penghasilan dari anggota keluarganya yang bekerja di dalam negeri. Hal ini kemudian membuat para perempuan tertarik melakukan mobilitas ke luar negeri untuk menjadi TKW. Tindakan ini termasuk ke dalam tindakan rasional. Tindakan rasional adalah tindakan yang dilakukan berdasarkan pikiran dan pertimbangan yang logis sesuai akal sehat manusia (Ritzer \& Goodman, 2010).

Alasan ketiga, yaitu ingin melepaskan diri dari lilitan hutang yang dialami. Adanya hutang pada diri TKW sebelum mereka bekerja di luar negeri menunjukkan bahwa mereka tidak bisa mendapatkan hidup yang layak di Indonesia. Alasan TKW bekerja di luar negeri karena hutang banyak ditemukan pada penelitian sebelumnya, salah satunya ditemukan oleh Djuwitaningsih (2019) yaitu alasan perempuan memilih bekerja sebagai TKW dikarenakan banyaknya hutang yang dimiliki, sehingga memunculkan anggapan bahwa jalan satu-satunya untuk dapat melunasi hutang adalah bekerja di luar negeri sebagai TKW. 


\subsection{Perubahan Sosial Keluarga TKW di Desa Dawung}

\subsubsection{Perubahan Peran}

Berdasarkan hasil penelitian, terdapat beberapa perubahan peran yang terjadi pada keluarga TKW di Desa Dawung. Pertama, perubahan peran mengurus pekerjaan rumah tangga. TKW yang bekerja di luar negeri berarti telah meninggalkan perannya untuk mengerjakan pekerjaan rumah tangga sehingga anggota keluarga harus menggantikan peran tersebut. Pada keluarga TKW di Desa Dawung, peran mengurus pekerjaan rumah tangga dilakukan oleh suami dan orangtua/mertua TKW. Ada suami TKW yang bisa mengurus pekerjaan rumah sendiri, namun ada pula suami TKW yang meminta bantuan orangtua/mertua TKW. Bagi suami TKW yang meminta bantuan pada orangtua/mertua merasa belum terbiasa untuk melakukan pekerjaan rumah tangga. Kebiasaan tercipta karena adanya perilaku yang diulang secara terusmenerus sehingga memunculkan kinerja yang baik (Hikmat, 2014).

Kedua, perubahan peran pencari nafkah keluarga. Besarnya penghasilan dari TKW membuat peran pencari nafkah yang awalnya dijalankan oleh suami digantikan oleh istri. Nafkah berarti pengeluaran yang diperuntukkan seseorang guna memenuhi kebutuhan hidup, baik itu berupa sandang, pangan, papan atau lainnya (Nelli, 2017). Peran istri sebagai pencari nafkah keluarga memberikan manfaat yang positif, yaitu kebutuhan rumah tangga akan terpenuhi dan suami juga merasa terbantu oleh istrinya (Machsuroh, 2018).

Ketiga, perubahan peran pembuat keputusan dalam keluarga. Pembuatan Keputusan adalah proses penetapan sesuatu dengan melalui pertimbangan dan pemikiran yang telah disetujui (Harahap, Sriyoto, \& Yuliarti, 2018). Pada keluarga TKW di Desa Dawung terjadi perubahan peran pengambil keputusan yang awalnya dilakukan oleh suami beralih dilakukan oleh istri. Hal ini bisa saja terjadi karena salah satu faktor yang mempengaruhi proses pembuatan keputusan dalam rumah tangga adalah penghasilan (Eliza, Ery, \& Kaswita, 2011). Istri yang bekerja sebagai TKW memiliki penghasilan yang lebih tinggi daripada suaminya, sehingga tidak heran apabila pada keluarga TKW istri memiliki peran untuk membuat keputusan.

\subsubsection{Perubahan Pola Pengasuhan Anak TKW}

Ketidakhadiran TKW dalam keluarga menyebabkan perubahan pola pengasuhan anak. Pada keluarga TKW di Desa Dawung anak dididik dan dirawat oleh suami dan orang tua/mertua TKW. Ada suami yang mampu mendidik dan merawat anak sendirian namun ada pula suami yang meminta bantuan orang tua/mertua. Suami yang meminta bantuan untuk mendidik dan merawat anak disebabkan harus membagi waktu antara bekerja dengan mendidik dan merawat anak. Hal ini sesuai dengan pendapat Putri (2014) yaitu meskipun kebutuhan utama keluarga telah dipenuhi seorang istri tidak menutup kemungkinan seorang suami memiliki usaha sendiri di rumahnya sehingga suami tetap dapat melakukan pekerjaan rumah tangga dan mengasuh anak dengan baik.

Di samping itu, ada anak TKW yang harus dididik dan dirawat oleh orang tua/mertua TKW sendiri tanpa bantuan dari suami TKW. Ada dua hal yang menyebabkan anak TKW dididik dan dirawat oleh orang tua/mertua TKW. Pertama, sifat keibuan yang tidak dimiliki suami TKW. Sifat keibuan adalah status atau pengalaman dalam mempunyai dan membesarkan anak (Prasetyo \& Putra, 2017). Sifat keibuan lebih banyak dimiliki oleh orang 
tua/mertua TKW karena sudah memiliki pengalaman dalam mendidik dan merawat anak, sehingga anak TKW lebih nyaman hidup bersamanya.

Kedua, suami TKW ikut bekerja di luar negeri sehingga orang tua/mertua TKW tidak memiliki pilihan lain selain mendidik dan merawat anak TKW. Dampak anak TKW dididik dan dirawat oleh orang tua/mertua TKW yaitu anak menjadi manja, anak sering membantah, namun hubungannya menjadi lebih dekat (Fatimah, 2017).

\subsubsection{Perubahan Gaya Hidup Keluarga TKW}

Besarnya penghasilan TKW menyebabkan perubahan gaya hidup pada keluarganya. Perubahan gaya hidup yang pertama adalah perubahan gaya berpakaian. Kebiasaan TKW untuk mengirimkan pakaian membuat keluarganya lebih suka menggunakan pakaian yang bermerek terkenal. Oleh karena itu, pakaian yang digunakan oleh keluarga TKW tidak hanya berfungsi sebagai pelindung tubuh melainkan juga berfungsi sebagai simbol status sosial. Status sosial adalah kedudukan atau posisi seseorang dalam kelompok masyarakat (Maniku, Sinolungan, \& Opod, 2014)

Perubahan yang kedua adalah perubahan alat transportasi. Besarnya penghasilan TKW membuat keluarganya mampu membeli alat transportasi yang dapat digunakan untuk mempermudah pekerjaan sehari-hari. Hal ini karena alat transportasi memudahkan seseorang untuk menjangkau sumber daya alam di suatu wilayah sehingga kebutuhan hidup dapat terpenuhi (Andriansyah, 2015).

\subsubsection{Perubahan Komunikasi}

Ditemukan bahwa terjadi perubahan komunikasi antara TKW dari Desa Dawung dengan keluarganya. Perubahan komunikasi ini disebabkan karena TKW tidak bisa bertemu dengan keluarganya sehingga komunikasi yang awalnya dilakukan secara langsung berubah menjadi tidak langsung, yaitu melalui media sosial. Media sosial adalah alat komunikasi berbasis online yang menguatkan hubungan antar pengguna sekaligus sebagai sebuah ikatan sosial (Nasrullah, 2017). Penggunaan media sosial untuk berkomunikasi membuat beberapa anggota keluarga TKW berusaha melakukan komunikasi secara intensif dengan TKW. Informasi ini didukung oleh pernyataan Sobandi \& Dewi (2017) komunikasi merupakan sesuatu yang harus dibina, sehingga anggota keluarga merasakan ikatan yang dalam serta saling membutuhkan.

\section{Simpulan}

Berdasarkan pembahasan di atas, maka dapat disimpulakan bahwa: pertama, TKW dari Desa Dawung memiliki beberapa karakteristik yaitu 1) Berusia produktif; 2) Memiliki tingkat pendidikan rendah; 3) Sudah menikah dan memiliki jumlah beban tanggungan dalam keluarga llebih dari 1 orang; 4) Jenis pekerjaan yang digeluti adalah Domestics Workers; 5) TKW bekerja di negara-negara Asia, yaitu Hongkong, Singapura dan Taiwan. Kedua, penyebab mobilitas ke luar negeri yang di lakukan oleh TKW adalah Desa Dawung adalah 1) Keinginan memperbaiki kondisi keluarga dengan mendirikan usaha dari penghasilan menjadi TKW; 2) Ingin memenuhi kebutuhan pendidikan anak; 3) Penghasilan dari bekerja di luar negeri lebih besar daripada penghasilan bekerja di dalam negeri; 4) Penghasilan dalam negeri tidak cukup untuk membayar hutang. Ketiga, perubahan Sosial pada Keluarga TKW di Desa Dawung, yaitu 1). Perubahan peran; 2) Perubahan komunikasi dan 3) Perubahan gaya hidup. 


\section{Daftar Rujukan}

Andriansyah. (2015). Manajemen Transportasi dalam Kajian dan Teori. Jakarta: FISIP Universitas Prof. Dr. Moestopo Beragama.

Badan Pusat Statistika Kabupaten Kediri. (2018). Kecamatan Ringinrejo dalam Angka. Kediri: Badan Pusat Statistika Kabupaten Kediri.

Dewi, N. A., Zukhri, A., \& Dunia, I. K. (2014). Analisis faktor-faktor penyebab anak putus sekolah usia pendidikan dasar di Kecamatan Gerokgak tahun2012/2013. Jurnal Pendidikan Ekonomi, 1-12.

Djuwitaningsih, E. W. (2019). Perubahan Perilaku Konsumtif dan Gaya Hidup Tenaga Kerja Wanita (TKW) Purna. Sosial Politik Humaniora, 7(1), 1-21.

Eliza, S., Ery, \& Kaswita, C. (2011). Analisis Faktor-faktor yang Mempengaruhi Konsumen Dalam Pengambilan Keputusan Pembelian Buah di Pasar Arengka (Pasar Tradisional dan Giant Hypermarket (Pasar Modern)) di Kecamatan Tampan Kota Pekanbaru. Indonesian Journal of Agricultural Economics, 2(1), 15- 34.

Fatimah, L. (2017). Migrasi dan Pengaruhnya Terhadap Pola Pengasuhan Anak TKW di Dusun Pangganglele Desa Arjowilangun Kecamatan Kalipare Kabupaten Malang. AntroUnairDotNet, 6(1), 108-122.

Febriani. (2013). Kualitas Pendidikan dan Keterampilan Tenaga Kerja Indonesia, Menuju Kesetaraan Upah di Luar Negeri. Jurnal Ekonomi Pembangunan, 14(2), 204-213.

Harahap, J., Sriyoto, S., \& Yuliarti, E. (2018). Faktor-faktor yang Mempengaruhi Pengambilan Keputusan Petani Salak dalam Memilih Saluran Pemasaran. Jurnal Agrisep, 17(1), 95-106.

Hikmat, A. (2014). Kreativitas, Kemampuan Membaca, dan Kemampuan Apresiasi Cerpen. Jakarta: Uhama Press.

Julaiha. (2013). Peranan Usaha Keripik Jagung dalam Meningkatkan Ekonomi Masyarakat Ditinjau Menurut Ekonomi Islam: Studi Kasus Kecamatan Teluk Meranti Kabupaten Pelalawan. Riau: Fakultas Syari'ah dan Ilmu Hukum UIN Syarif Kasim.

Lee, E. S. (1966). A Theory of Migration. Demography, 3(1), 47-57.

Machsuroh, F. (2018). Pertukaran Peran Pencari Nafkah Utama Dalam Keluarga: Studi Kasus di Desa Lengkong Kecamatan Sukorejo Kabupaten Ponorogo. Ponorogo: Fakultas Syariah Institut Agama Islam Negeri Ponorogo.

Maniku, S. F., Sinolungan, J. S., \& Opod, H. (2014). Hubungan Kebahagiaan Dengan Status Sosial Pada Keluarga di Kelurahan Tanjung Batu. Jurnal e-Biomedik (eBM), 2(3), 1-4.

Marita, \& Waridin. (2013). Analisis pengaruh upah, pendidikan, jumlah tanggungan keluarga dan status perkawinan terhadap curahan jam kerja wanita di Kecamatan Pedurungan dan Kecamatan Tembalang Kota Semarang. Diponegoro Journal of Economics, 2(1), 1-13.

Moleong, J. (2016). Metodologi Penelitian Kualitatif. Jakarta: Departemen Pendidikan dan Kebudayaan Direktorat Jendral Pendidikan Tinggi Proyek Pengembangan Lembaga Pendidikan Tenaga Kependidikan.

Nasrullah, R. (2017). Media Sosial: Perspektif Komunikasi, Budaya, dan Sosioteknologi. Bandung: Remaja Rosdakarya.

Nelli, J. (2017). Analisis Tentang Kewajiban Nafkah Keluarga Dalam Pemberlakukan Harta Bersama. Jurnal Hukum Islam, 2(1), 30-46.

Prasetyo, I. H., \& Putra, B. A. (2017). Penerimaan Diri Pada Wanita Involuntary Childless (Ketiadaan Anak Tanpa Kerelaan). Jurnal Psikologi Kepribadian dan Sosial, 6(1), 39-48.

Putri, K. A. (2014). Pembentukan Couple Types Berdasarkan Komunikasi Dalam Menjalankan Role Family Function Pada Keluarga Dengan Stay At Home Dad. Commonline Departemen Komunikasi, 3(1), 154166.

Ritzer, G., \& Goodman, D. J. (2010). Teori Sosiologi Modern. Jakarta: Kencana.

Sobandi, O., \& Dewi, N. (2017). Urgensi Komunikasi dan Interaksi Dalam Keluarga. Islamic Religion Teaching and Learning Journal, 2(1), 53-62.

Sugiyono. (2016). Metode Penelitian Kuantitatif, Kualitatif, dan R\&D. Bandung: Alfabeta Bandung.

Sukmaningrum, A. \&. (2017). Memanfaatkan Usia Produktif Dengan Usaha Kreatif Industri Pembuatan Kaos Pada Remaja di Gresik. Paradigma, 5(3), 1-5. 
Jurnal Integrasi dan Harmoni Inovatif Ilmu-Ilmu Sosial (JIHI3S), 1(2), 2021, 151-159

Turatmiyah, S., \& Annalisa. (2013). Pengakuan Hak-hak Perempuan Sebagai Pekerja Rumah Tangga (Domestic Workers) Sebagai Bentuk Perlindungan Hukum Menurut Hukum Positif Indonesia. Jurnal Dinamika Hukum, 13(1), 51-58.

Undang-Undang Republik Indonesia Nomor 39 Tahun 2004 Tentang Penempatan dan Perlindungan Tenaga Kerja Indonesia di Luar Negeri.

Wulandari, I. (2013). Pola Perilaku Konsumtif Tenaga Kerja Wanita (TKW) Ketika Kembali ke Daerah Asal di Kecamatan Ponggok Kabupaten Blitar. FKIP UNS: Surakarta.

Yuniastuti. (2014). Kehidupan Sosial Ekonomi TKI dan TKW Serta Dampak Sosial Psikologis Pendidikan Anak. Jurnal Pendidikan Pancasila dan Kewarganegaraan, 27(1), 65-70. 